\title{
Shops with a history and public policy
}

\section{Teresa Barata-Salgueiro}

To cite this article: Teresa Barata-Salgueiro (2021): Shops with a history and public policy, The International Review of Retail, Distribution and Consumer Research, DOI: 10.1080/09593969.2021.1873816

To link to this article: https://doi.org/10.1080/09593969.2021.1873816

曲 Published online: 18 Jan 2021.

Submit your article to this journal $₫$

Џll Article views: 20

Q View related articles $₫$

View Crossmark data $\asymp$ 


\title{
Shops with a history and public policy
}

\author{
Teresa Barata-Salgueiro (iD \\ University of Lisbon, IGOT, Institute of Geography and Spatial Planning, Edifício IGOT, Rua Branca Edmée \\ Marques, Lisboa, Portugal
}

\begin{abstract}
A program to support historical shops was recently created in Lisbon; called 'Lojas com História', it was later extended to other cities in the country. This paper shows the changes in public policy towards retail in Portugal where one finds an evolution from purely government regulation to a policing context aiming to strengthen competition between businesses, which endowed the sector with a growing role both in city policy and planning, and competition between cities. The evolution of policies reflects an increased focus on place with a shift from the support to commercial units, to strengthen their competitiveness, to their valorisation in the context of competition between cities. On the other hand, it is argued that this evolution is linked to the reinforcement of entrepreneurship in urban management. After recalling the social and spatial functions of retail and the changes in policies towards retail, we present the program and some characteristics of the shops covered by this program in Lisbon, followed by a first review and considerations on the challenges it brings.
\end{abstract}

\section{ARTICLE HISTORY}

Received 29 January 2020 Accepted 6 January 2021

\section{KEYWORDS}

Historical shops; retail policy; competition; heritage;

Lisbon

\section{Introduction}

In recent years there has been a movement to protect the historical shops in Portugal. It was stimulated by the multiplication of old shops closures, partly due to the increase in rental prices or the owners' refusal to renew the leasing contracts, with the entry into force of a new urban lease law. The process has culminated in the approval of a public support program.

This paper analyses this program in the context of policy measures taken to support retailing, along with changes in public policy and forms of governance. The argument has two interconnected components. On the one hand, we seek to show that the evolution of public policy vis-à-vis independent retail reflects a growing focus on place, as a shift was observed from the support to retail units, to their valorisation in the competition between places. On the other hand, this evolution is linked to the strengthening of entrepreneurship in urban management. Policy change reflects the reorganization of the state, with increased decentralization, and the application of new forms of management aiming to attract investments and visitors. Besides seeking to alleviate immediate difficulties later explained, the distinction of 'Lojas com História' (Shops with a history, from now on 'LH'), awarded by the Lisbon municipality, comes from the recognition that shops also have cultural value as elements of distinction able to contribute to the specificity of the place, 
a prerequisite for the global competition between cities. The shops covered by the program have a heritage value, not merely in terms of architecture or decoration but also by the cultural values associated with its operation. They have a story to tell and are part of the memory of the city, remembering people, events, or forms of doing business almost lost.

The main sources of information are legislation and regulations, the municipal database of the shops incorporated in the program up to 31 December 2018, and the application forms submitted to the program. We also have conducted in-depth interviews with the chair of the Lisbon municipal working group in charge of the program, and with stakeholders, seeking to make a preliminary evaluation of the program in terms of points of interest and problems, changes introduced in the shops after being awarded the distinction, and to collect ideas to support more effectively the participating shops. The interviewees include academicians, members of the board of directors of commercial associations and of an independent association for retail heritage, and shop owners or managers. An intense fieldwork with visits, in-place observations and informal conversation was undertaken between January and June 2019.

The paper is structured in four parts. After this introduction, the spatial dimension of urban retail and its change with the enlargement of the society of consumption are recalled, to understand how retailing is again a relevant element in the attraction and competition between cities. This is followed by a summary of the features of public intervention and retail governance in Portugal. Then the ' $\mathrm{LH}^{\prime}$ program in Lisbon is presented illustrating the new level reached by retail policy and some problems arising from its application. Finally, a conclusive synthesis is made, followed by a first review and considerations on the challenges the program brings.

\section{Retail as element of urban competitiveness}

The importance of retail goes beyond the exchange of goods because, in addition to its economic function, retail has both a social and a spatial dimension. Retail clusters help to combat desertification and insecurity turning streets and neighbourhoods into liveable and vibrant places. At the same time, the relationship between retail and the city can be examined according to two dimensions, the material dimension of the city and its retail landscapes and the symbolic dimension of the mindscapes associated with them. This text privileges the cultural and symbolic dimension that commerce supports.

The expansion of the consumer society in which conspicuous consumption of objects and places helps consumers to compose their identities in the dialog with the objects and shopping places (Veblen 1899; Cachinho 2006, 2011; De Simone 2017), explains why retail premises become supportive spaces for transactions in the symbolic realm by exploring their architecture and layout (Goss 1993), and transform themselves into a commodity to meet also the human desire of dreaming and escape from reality.

In the new retail environments people can enjoy themselves, make their dreams and fantasies come true (even just for a moment), live experiences. The trend for shops offering experiences as been underlined by Pine and Gilmore (1999), Cachinho (2002), Klingman (2007), while the new role of consumers that are both spectators and actors leads Cachinho (2006) to speak of consumactors or Bäckström (2006) of recreational shoppers. In the same fashion, Roozen (2019) shows the influence of exterior elements, 
like window displays and the aspect of the store entry, on clothing store entry intentions for recreationally and task-oriented female shoppers.

The need to have certain goods, to attend the right shops or restaurants also helps to explain shopping tourism that brings shoppers from the far east or from the south (especially Latin America and Africa) to Paris or Dubai, and Scandinavians to the bargains of the Barcelona sales (Arino Barrera 2009). Shopping tourism is sometimes propelled by commodification that transforms services and goods that were daily needs into commercial goods attractive to tourists and their recreation needs as Najmi, Pratiwi, and Harun (2015) show for Bandung. These shopping movements give new vitality to luxury shopping streets (Cachinho 2015), justify the success of museum's shops and the 'brand museums' that explore the commodification of arts, the cross- fertilisation of arts and management (Chaney, Pulh, and Mencarelli 2018) between culture and brands. At a smaller scale, D'Alessandro (2015) reports recent changes in the central areas that have brought renewed attractiveness to consumption and its practices.

The symbolic character of the places is a cultural product that results from their appropriation, the image they present and the representations they support, contributing to the distinctive character of the various sites (Barata-Salgueiro 2013). Globalisation has brought the presence of the same goods and brands in identical shops in many cities around the world that offer an increasingly similar commercial landscape. On the one hand, this similarity gives the security of the familiar to increasingly mobile consumers; but for the ones looking for the unique that makes the difference, this uniformity is boring and uninteresting to visit.

Shopping spaces are part of the townscape and everyday life, they are part of our image of places which can be a banal, standardised image or a special, characteristic, individualised one; but shops can also refer to images and past experiences in a distant time. By staying for many years in the same place and with the same characteristics, some outlets become repositories of a social past and evolution and, as such, contribute to the collective memory of space and its character. Some shops were the scene of memorable events and are or were frequented by certain groups, being places of memory and identity. Others have a rich heritage in terms of architecture, decor or booty that makes them unquestionable references in the physical and cultural landscape. All, although for different reasons, can participate in the storytelling process and be a reason for visiting, by tourists and locals. Habitual users find in them pillars of their spatiality and remembrance of events that they have lived or heard about, people and habits that are no longer present or, on the contrary, environments and goods that only the permanence of certain shops keeps possible.

Even at the neighbourhood level the cultural heritage conveyed by the shops in their mutual relationship of physical proximity, leads Zukin (2012) to consider the stabilized commercial street the result of the interdependencies established between shopkeepers, housewives, workers in the area and children, in their daily appropriation of the street. This type of street 'provides a theatre for performing a ritualized script of urban sociality', equivalent to the ballet described by Jacobs (1961) and continues to inform the idea of the neighbourhood-community of many city dwellers. Coca-Stefaniak, Parker, and Rees (2010) also underline the community embeddedness and meaningful relations between shop owners and customers as key pillars local retailers have to counterbalance globalisation.

Besides the local shoppers that attend these shops by habit or convenience, nostalgic or new contemporary tourists also enjoy finding these unique treasures in the places they visit. We may recall a pastry shop in Lisbon that is sporadically visited by former consumers, 
nostalgists of their past which includes sitting at one of the tables for long hours just chatting or watching bystanders. Many owners of the shops incorporated in the program 'LH' in Lisbon note that they are visited by tourists watching and making pictures and sometimes also buying.

The growth and diversification of tourism and the demand made by many visitors, investors, and some residents for specific and unique features characteristic of each place, justify the use of commerce as an asset that enhances the specificity of the cities. Thomsen (2018) shows how a heritage site may provide a context for tourism retail development as tourists like to buy place-specific products to remind them of the place they visited. Indeed, retail tends to be a pillar of the city's branding in attracting tourists, as Rabbiosi (2016) shows for the regional food and wine shops in Rimini. This reinforces the idea that, with globalisation, the value of difference between places is increasingly branded and reflected in the objects of consumption and the ideas they stimulate. With increasing competition between places to attract visitors, capital and residents this role of retail has gained more visibility.

\section{Public policy and governance}

Apart from licensing and other rules on opening hours, hygienic and safe conditions, and traditional retail markets (Guimarães 2018a), retail had little place in public policy. In urban planning it was reduced to the zoning ordinances, informed by the principles of range and threshold of goods of the theory of central places. While retail premises shared residential buildings, this indication was at most limited to pointing out the main streets where they could be.

Since the mid-1960s, the so-called retail revolution, based on new techniques and forms of organisation, has led, on the one hand, to increase the size of businesses; and, on the other hand, to new locational patterns of shops and consumer's behaviour. With the increased political and economic weight of large players (distribution corporations often with presence in several countries), the marginal part of the upper circuit of the urban economy constituted by independent retailers acquired more visibility: some small and medium-sized retail businesses have collapsed, while others became franchisees of big chains (Silveira 2016). It was then imperative to change the way public intervention was carried out. In Western Europe this led to policy differentiation between liberals arguing that planning should not constrain modernisation due to the benefits it brings in terms of price reductions and widening consumers' choice, and those more concerned with ensuring fair access to all types of consumers, something that large out-of-town structures threatened (Davies 1995). Findlay and Sparks (2014) systematize the points of the debate between modernization and productivity versus the danger of the fossilization of outdated models and inefficient practices, beyond the question of equal access and competition between locations.

Shopping centres are often planned to anchor new developments, but the importance of retail increased when it acquired a prominent role in the regeneration of brownfields or waterfronts and in the revitalisation of downtown districts (Balsas 2001; Guy 2007; D'Alessandro and Salaris 2011; Wrigley and Dolega 2011; Parker et al. 2016; Tselios, Lambiri and Dolega 2018). In Lisbon, the important regeneration of the eastern waterfront has a shopping centre in a central location. The reconstruction and revitalization of Chiado 
(the core of the city centre), after the 1988 fire, also had a shopping centre in the place of the old decaying department store.

With recent changes in the levels of political decision-making and increasing space competition, places and regions are becoming more prominent and changes in modes of governance can be seen. Local authorities acquire entrepreneurial characteristics as Harvey (1989) has identified, and enter global competition to capture investments, jobs, and visitors to respond to the needs of economic growth as often stated by local coalitions or growth machines (Molotch 1976). In the society of hyperconsumption (Lipovetsky 2006) new logics in the production of urban space and urban management are applied, aiming to seduce and attract consumers. They need to offer a positive image of the city turned into a commodity, object of promotion and branding. So, marketing campaigns and events with great attractiveness of people and companies multiply everywhere; also, heritage aspects, including shops (Peck, Theodore, and Brenner 2013; BarataSalgueiro 2013; Barata-Salgueiro, Mendes, and Guimarães 2017; Olivera 2015) are part of the package sold to visitors.

Another significant aspect of the change are the more participatory forms of planning and the provision of services in association with the private sector and non-market organizations, which represents a move from public government to associated or delegated forms of governance. Forms of participatory management of commercial areas have then multiplied, as exemplified by the Town Centre Management schemes (TCM) and Business Improvement Districts (BID).

After entering the EU, in 1986, and the expansion of the new forms of distribution (multiples, chains and out-of-town superstores), in Portugal, the pressure exerted by the representatives of the independent retail grew and new measures were tested, aimed to hinder the licensing of new large retail developments and the liberalization of opening hours. Public policy became reactive both through the licencing of superstores and shopping centres and their functioning, and the development of EU funded programs towards supporting the modernization of traditional independent retailers (Cachinho and Barata-Salgueiro 2016). The post-entrance in the EU period saw the mobilisation of the Structural Funds for training and technical assistance programs to modernize the retail system in order to strengthen small independent retailers in face of competition from large retailers (Cachinho 1992; Fernandes 1994, 2007; Balsas 1999; Guimarães 2015). The first program (1991-93) was intended to 'contribute to the balanced development of the regions and the modernization of the retail system by encouraging innovation and the transformation of retail business' (Guimarães 2015, 169, my emphasis) and provided nonrepayable funding for expenses related to the physical modernization of the retail premises, including computer hardware, technical assistance and consultancy. After 2000 the diversity of retail formats, the adoption of consumer culture and its consequences for shops' ambiance already mentioned, and more concerns with environmental questions and town planning explain the publication of laws aiming to constrain the out-of-town retail locations, and the redesign of the support programs in order to strengthen the relationship between retail and the city (Cachinho and Barata-Salgueiro 2016). As matter of fact, the second program as well as the subsequent ones (1994-2008) that also pursued the objective of 'promoting the sustainable development of the competitiveness of businesses within a coherent strategy for modernizing their activity' (id. ibid., 171), were already part of the 'special projects of commercial urbanism' which have a spatial dimension, as 
the delimitation of areas of intervention was required. Therefore, the focus shifted from the support to isolated shops regardless of their location to the support of shops only if they were in a given area, usually the high street. In addition to retail businesses, these programs provided funds for municipalities to carry out some interventions mainly in public space, and for retail associations to develop marketing campaigns, as well as other initiatives. Directly or indirectly, these projects have facilitated partnerships and major urban regeneration operations, particularly in high streets or waterfronts of many cities. So, they show an understanding that it was not enough to support individualised shops, but a more comprehensive action was necessary, with interventions in the physical environment of the retail clusters.

In the context of huge rehabilitation and touristification of the inner city, a new challenge arises for traditional independent retailers. The program ' $\mathrm{LH}^{\prime}$ tries to answer it in Lisbon.

\section{The program for 'shops with a history' in Lisbon}

In 2016 and 2017 the newspapers noticed the closure of numerous emblematic shops and restaurants in Lisbon and pointed as causes both the change in the tenancy law that facilitates evictions, and the tourist pressure that leads to changes in the retail profile of the districts where its impact was more intense. Indeed, the effectiveness of the rehabilitation of buildings became reason for ending the lease, and the liberalisation of the rents explains that many shops were evicted or unable to pay the higher rent demanded by the owners.

Aware of this crisis of traditional retail, the Lisbon City Council launched the Program 'Shops with a History' in February 2015, with the constitution of a task force. The proposal was presented by the councillors of urbanism, economic activity, and culture, reflecting the need to articulate different areas of municipal activity. In the justification for the initiative (CML (Câmara Municipal de Lisboa) 2015, 20) it's possible to understand their motives: 'In a global and highly competitive world, each city needs to enhance the diversity that makes it special, and more attractive to visit, study, work or invest. Urban retail is one of the distinctive elements and differentiator between cities'. The role of retail as a differentiating element is therefore valued and useful in the competition between places to attract people and investments.

From the work developed by the task force, until February 2017, a set of units were distinguished, and the proposal of the Municipal Regulation for the attribution of the distinction approved. Data collection in several sources and criteria trial to more than 300 units, accompanied by discussion with stakeholders and experts led to choose 82 almost unquestionable units. Afterwards, each business that thinks it meets the criteria established, their workers or civil society may apply for the distinction. The criteria adopted encompass three components: business longevity, material heritage, cultural and historical heritage. Long-life business presupposes a minimum of 25 years of continuous activity in the same place, although the evaluation of these criteria values the older ones. Twentyfive years is arbitrary and in Barcelona the threshold is 50 years (Carreras and Frago 2016). Although we do not know how long they will last in the memory of the city, there are relatively recent units that have gained high visibility and are already a reason for attraction and visit. The age dilemma refers to the ambiguity that Zukin (2009) attributes 
to the concept of authenticity that represents 'origins' in two different directions. On the one hand, an almost mythical rooting in space and time; on the other, an ability to produce historically new creative innovations. The same problem with authenticity and the configuration of a pseudo-old 'tailor city' for tourists led Thomsen (2018) to speak of 'planned authenticity', the outcome of interventions that lead to increase in the significance of activities and products that were not specially attached to a place in the past.

In the criteria adopted in Lisbon, heritage encompasses material and non-material dimensions: the architecture, the ambiance, the artifacts used, archives and stories about the shop and the place. The program gives recognition to shops that are significant for the city's own identity, which is different from being classified as a heritage element. Both processes intend preservation, but they have different consequences for the units, as the classification is stronger in legal terms and more restrictive about changes than the distinction. Besides the recognition awarded, the establishments enjoy a set of benefits that include a signpost for the shop's façade, access to a financial instrument that supports conservation and restoration works, cultural initiatives, promotional materials, and professional consultancy. The municipality was concerned with the disclosure of this heritage component for which a website was created (http://lojascomhistoria.pt/) where, besides useful information, one can find the location, pictures and a brief story of each premise, both in Portuguese and English. An exhibition presenting pictures and pieces from the distinguished shops was also organized in the fall of 2017. However, it was understood that these measures were not effective to prevent the causes of the closures, which required measures at upper level, like legislative changes. By pressure of the mayor of Lisbon, in June 2017, a law was published establishing a special regime of recognition and protection of establishments and entities with local historical, cultural or social interest. At the same time, other cities started similar programs to the one developed in Lisbon (Chamusca et al. 2017).

\section{The main features of the stores}

In the city of Lisbon, 145 retail units were awarded with the distinction up to December 2018 and they are the focus of the following analysis. Seventeen per cent of the units were already in operation in the third quarter of the 19th century, and a further $19 \%$ opened in the transitional period corresponding to the belle époque (Table 1), a period that marks the decoration of many of them. So, a little over a third are prior to the WWI. A similar amount opened doors until the start of WWII. Twenty-four per cent of the units were inaugurated between 1940 and 1961, but the number of the distinguished after that year decreased. Of the 145 premises only 140 are in operation; in the meantime, five have closed.

In the oldest one finds a bookstore, two cafes from 1782 to 1787, a luxury restaurant from 1784 and a candle shop. The bookstore claims to be the oldest in the world. Born in 1732, it occupied the actual building in 1773, after the rebuilding of the district destroyed by the earthquake of 1755; the candle shop dating from 1789 still has in the back the workshop to make the candles.

Although most of the units and the oldest ones are concentrated in Baixa-Chiado, the traditional city core, the location shows a relatively dispersed pattern which reflects the city's growth (Figure 1). In 1913, only two were far from the centre, a pastry-shop in the west side of the city, at Belém, and a restaurant in the North, at the frontier with, at the time, still fields. Until the late 1930s, there was a continuous strengthening of the city core but a second wave starts 
Table 1. Shops opening period.

\begin{tabular}{lccc}
\hline & \multicolumn{2}{c}{ Stores } & \\
\cline { 2 - 3 } Period & Absolute numbers & $\%$ & Closed \\
\hline 1732 to 1840 & 14 & 9.66 & \\
1857 to 1878 & 10 & 6.90 & \\
1883 to 1913 & 27 & 18.62 & 1 \\
1915 to 1938 & 42 & 28.97 & 4 \\
1940 to 1961 & 35 & 24.14 & \\
1964 to 1989 & 17 & 11.72 & \\
Total & 145 & 100.00 & \\
\hline
\end{tabular}

Source: Municipality of Lisbon adapted by the author

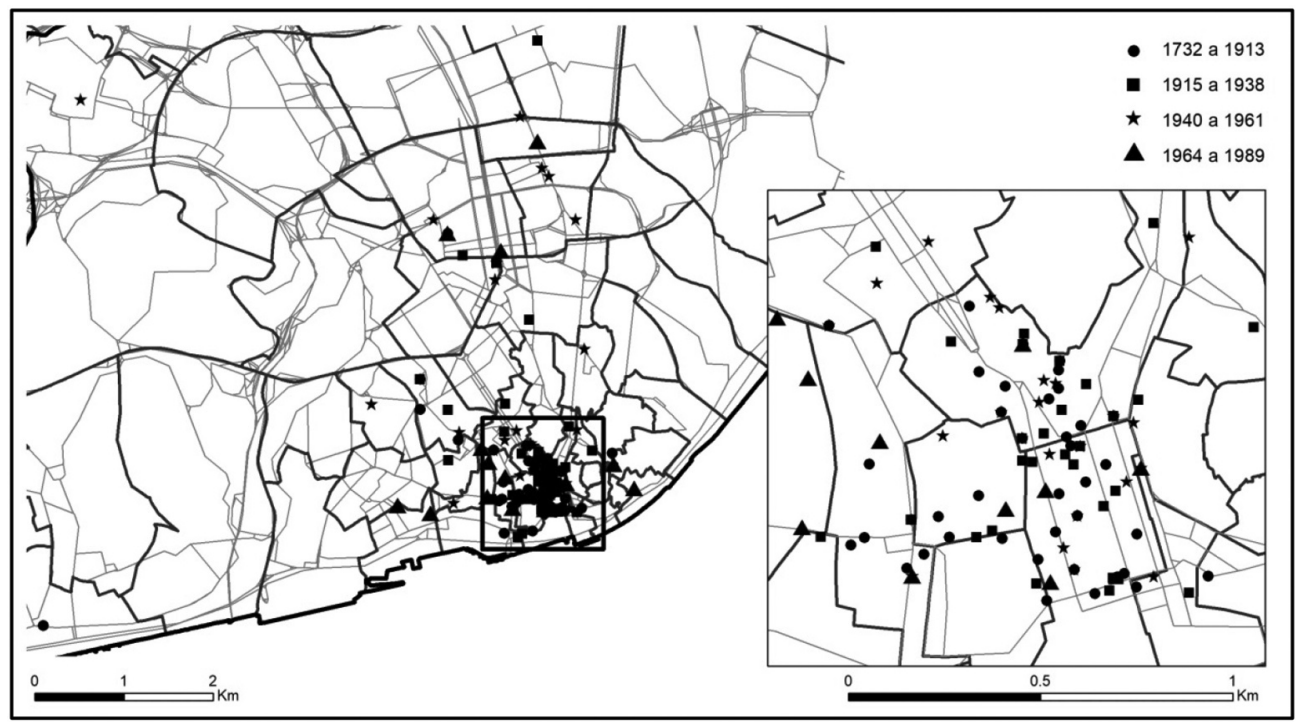

Figure 1. The shops in the Program by opening period. Source: Municipality of Lisbon with treatment by the author. Cartography by Marcos Correia

as retail premises open in the neighbourhoods built at the beginning of the twentieth century, especially in the bourgeois boulevards called Avenidas Novas, and later in the communities built in the 1950s and 1960s, following the construction of the city. Finally, in the 17 units opened between 1964 and 1989, no area stands out, revealing the reconfiguration of the city's commercial offer, less polarized in a single centre but with a hierarchical structure.

The best-represented retail typology is restaurants, bars, cafes, and other similar units (Table 2). The conviviality of these places where people meet regularly helps to associate

Table 2. Units studied by typology.

\begin{tabular}{lcl}
\hline Typology & Absolute numbers & $\%$ \\
\hline Personal goods & 34 & 23.45 \\
Culture and leisure goods & 25 & 17.24 \\
Cafes, restaurants and similar & 37 & 25.52 \\
Other & 49 & 33.79 \\
Total & 145 & 100.00 \\
\hline
\end{tabular}

Source: Lisbon Municipality adapted by the author 


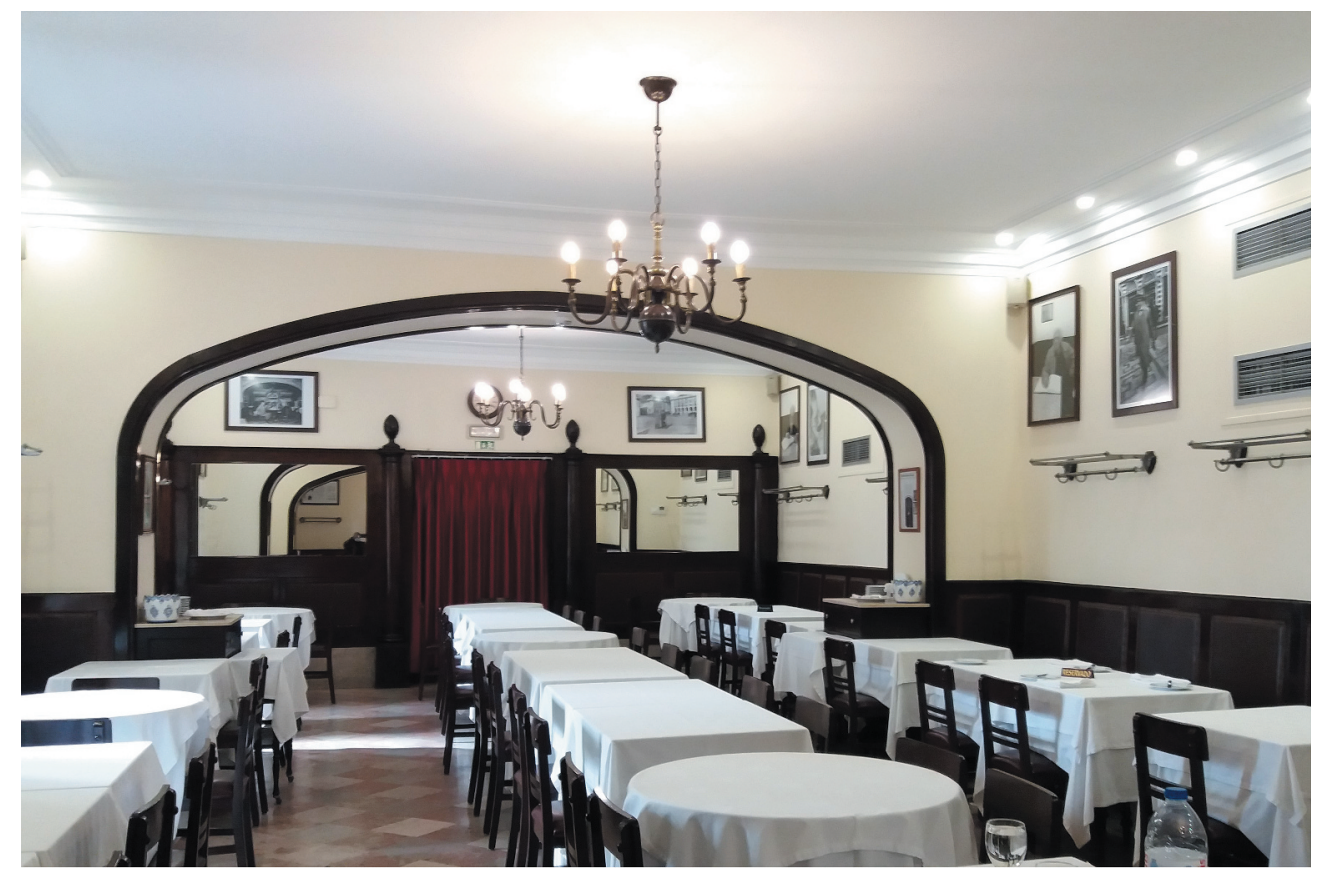

Figure 2. Memories of artists at restaurant-cafe Martinho da Arcada. Photo by the author, 2020

stories with them. The oldest cafe-restaurant of the city Martinho da Arcada (opened in 1782 selling drinks and ice, but with the actual name and function from 1829) was a famous meeting place for politicians, businessmen and artists. Keeping the décor of the 1930s it displays pictures and other references to Pessoa, the most famous poet of Portugal in the $x^{\text {th }}$ century, and other writers (Figure 2). Another cafe associated with this writer and other artists is the Brasileira do Chiado founded by an emigrant returned from Brazil in 1905. In the 1980s a sculpture representing Pessoa seated at the coffee table was put on the sidewalk as tribute to the poet by the municipal council (Figure 3). Another possible explanation for the strong presence of cafes and restaurants in the shops which received recognition as having a history has to do with their resilience. People always need meeting places, to chat around a table and drinks, so it is easier to keep the business viable for a long time.

In second place one finds the personal goods, culture and leisure shopping facilities. The less represented retail typologies are tools and professional equipment, drugs and health care, and repair services, less dependent on passing-by shoppers. Also, with a relatively modest representation (around 10\%) come food stores and homeware shops. These last ones combine antiques with shops selling curtains, rugs and crockery.

In the city centre one finds all retail typologies with strong representation of premises from the same three most important typologies. Professional goods and homeware premises have scarce representation, as well as food stores. The ones that exist in the area are although very specialized and with high-quality goods (wines, tea and coffees, cheese, chocolates). 


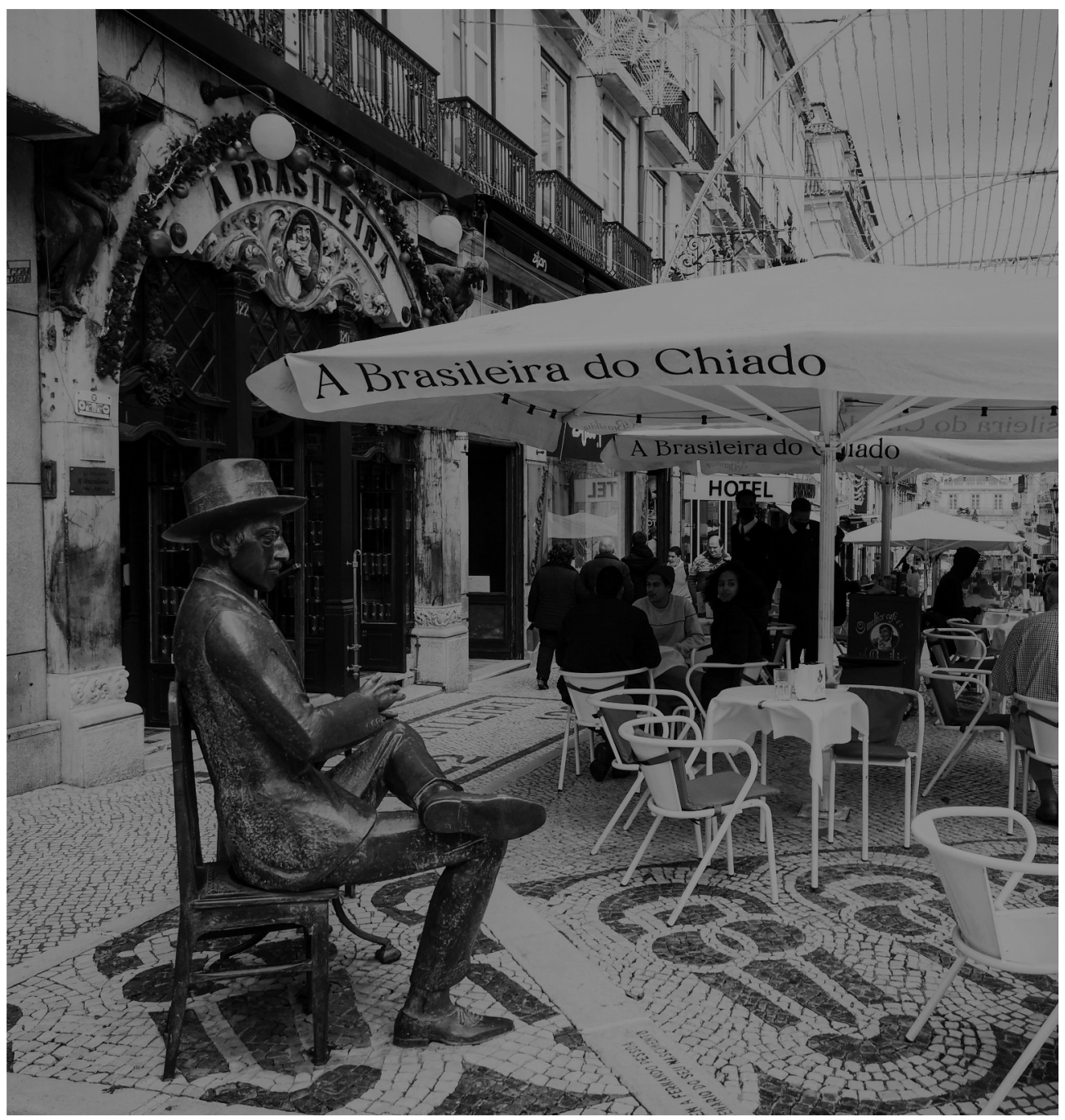

Figure 3. Sculpture of the poet Pessoa close to the cafe A Brasileira do Chiado. Photo by H. Cachinho, 2020

An analysis of the documents prepared by business owners when they applied for the program's recognition allows us to comprehend the reasons that justify the incorporation of their premise in the program. It was possible to have access to the justification made by 58 business owners with a total of 181 references as some mention more than one reason. It is important to underline that this represents $92 \%$ of all the applications since the first 82 outlets were distinguished after the working group's survey and, at that time, an application form was not required.

Contrary to what is expected, and what some authors say about merchants' pride in their business (Yunus, Samadi, and Omar 2015), the justifications are generally poor and essentially seek to meet the criteria approved by the municipality. Mentions are broadly divided into four groups: supply characteristics, space and management, customers, 
Table 3. Presentation of the shops by the business owners.

\begin{tabular}{lcc}
\hline Category & No of References & $\%$ \\
\hline Characteristics of the offer & 51 & 28.2 \\
Space and management & 100 & 55.2 \\
Customers & 17 & 9.4 \\
Mission and outreach & 13 & 7.2 \\
Total & 181 & 100.0 \\
\hline
\end{tabular}

Source: Lisbon Municipality adaptedt by the author

mission and outreach, as shown in Table 3. In the first group, the items sold, the quality attested in their manufacture and the level of brands marketed assumes importance. Reputation and pioneering or being one of the few survivors in the industry are also referred to; finally, some retailers mention the quality of the services offered.

The age of the shop, the type of business industry or the permanence in the same family is the item that receives the most references in 'Space and management' category. The material heritage that includes preserving the original lay-out, architecture, decoration or furniture, in addition to other material assets is also referred. These latter include work equipment, such as cash register, tools, moulds, customer files, or recipes for making the product they sell.

There are also 14 mentions of the ambiance of the shop that relates to an non-material dimension. They state that the shop is welcoming, intimate, and typical, with character; invoking the memories of encounters or events that took place in past eras; and the appeal of the place to the experience and symbolism of the objects it sells. The owners of restaurants, cafes or bookstores are the ones that mention the ambiance more often. In the bookstores they evoke, for instance, the sale of books or records prohibited by censorship under the previous regime. Customers help to make the ambiance as mentioned. Specifically, regarding customers, there is the appreciation of hosting certain groups such as artists, journalists, gays, businesspeople, politicians, or other well-known persons which remembrance Figure 2 shows. In the customer's origin, the geographic scale appears again when they say 'they are from the neighbourhood and foreigners, they are from here and from around the world', a reference to the Portuguese diaspora who, when they return home, visit the old places they used to attend.

Other important element for the business concerns location, and they clearly distinguish three scales, the city, the building, and the shop. The scale of the city refers to the district where the shop is located, sometimes qualified by proximity to a point of people or tourist crossing or concentration. The scale of the building concerns the period of construction or architectural value. For the retail premise reference is made to the fact that it occupies the space of another one, of which it has retained some decorative elements. This is also a means of telling a story of industry continuity and heritage preservation.

Few owners refer to the fourth group, called 'Mission and outreach'. The latter basically includes the existence of Facebook pages to advertise the premise and its reasons of interest. Only five applications mention what they feel is their mission or contribution to society: 'identifying, estimating, sharing and disseminating the enjoyment of a particular product (...) promoting artists (...) contributing to tourism development (...) evoke a commitment to be the best among the best '.

The interviewed stakeholders underlined as positive the public recognition of the old shops and recognise that the distinction will improve the self-esteem of retailers, although 
almost no change in their business behaviour or strategy is seen so far. They also think the program can sensitize building owners and technicians to the value they get by maintaining the old shop instead of replacing it with a hotel lobby or similar; but to keep the old stores requires investment in their maintenance, eventually in partnership with the tenants. They also gave some ideas in order to improve the program. They include articulation with the Lisbon Tourism bureau to dispense, in hotels and tourism information points, flyers and other promotional materials to stimulate the visit to the awarded shops with the distinction. Another idea concerns the creation of an agency of investment which manages a portfolio of potential sites for investment. This institution could resemble a TCM or BID and would also be in charge of some activities or promotional materials. The municipality fund to support the distinguished shops might be used to finance this institution, instead of financing individual shops. That institution should engage the municipality, the commercial associations and other stakeholders. Up to now, UACS (Union of the Associations of Commerce and Services) provides information and technical support in the submission procedures to the program, but only approximately $50 \%$ of the distinguished retail units are members of the association. One of the interviewers admits the process requires three steps: protection against closure; boost sustainability; and ensure requalification. So far it only looked at the first, so there is still a long way to go.

\section{Final remarks}

The paper shows the changes in public policy towards retail in Portugal from purely regulatory policies - norms on licencing and rules on industry's operation - to a situation aiming to strengthen competition between firms, culminating in endowing the sector with a growing role both in city planning and policy, and in the toolkit used in the competition between cities. The support to retailing began by focusing on shops, aiming to facilitate their modernization and strengthen the competitiveness of the businesses. In a second moment, support to retail is integrated into urban policy, and the focus moves to the revitalisation of high streets, a form of retail urbanism aiming both the development of the retail function and the well-being of people (Mérenne-Schoumaker and Browet 1988; Cachinho 1992). With increasing competition between places and the need to offer unique and differentiating features, entrepreneurial urban management has also begun to use retail premises as a cultural resource, a differentiating mark of the city, an instrument to enhance the attractiveness of the city for tourists, other users and investors. This evolution is due to three main factors whose importance has occurred over time: the concentration effects of large corporations on the geography of the retail offer, changes in government, and in public policy. In terms of government, one has assisted in the restructuring of sub-municipal authorities both in terms of geography and competences, not analysed in this paper, and the growth of shared forms of governance. Changes in policy refer to the new role given to retail to attract investments, not only to improve businesses, but also to stimulate the regeneration process of the selected areas (Findlay and Sparks 2014), often central cities and other derelict areas. This change also shows a trend to policy integration because it began with the economic and urban realms within the commercial urbanism and now extends to the cultural dimension, which justifies the proposal of the program ' $\mathrm{LH}^{\prime}$ in Lisbon being presented by councillors responsible for these three areas of municipal management. 
The development of the program ' $\mathrm{LH}^{\prime}$ also points to the need to adopt policy measures at various levels. The study shows that a local initiative, to be effective, required framing, namely policy responses at national level, specifically in terms of law production or adjustment. At the same time, it shows how the national-level reaction to a local initiative had positive indirect effects by encouraging the implementation of a similar program in other cities of the country.

The program was motivated by a sense of urgency as to the need for the conservation and revitalisation of these activities, and the recognition of their importance for the city's character and differentiation, when the city was experiencing a huge growth in tourism. Without specification how, the program admitted an assessment after some time, but so far there has been no formal evaluation. In a first assessment of the program one must recognise merits, but also problems, some of which require short-term measures. From the standpoint of retail units, it allowed three important things: recognition of their contribution to the city's character and memory, access to a municipal support fund, albeit still with limited success, and, in the case of tenants, a postponement of the negative effects of the 2011 tenancy law. At the city level, the wave of closures that were underway was stemmed and the awareness of the cultural and heritage importance of retail outlets was widespread in the public opinion, and put on the agenda for investors, and even for city planning technicians.

There are also three aspects that call for reflection and possible correction. The first concerns the revision of the criteria or their relative weighting to make the decision about whether the shops fit in the program clearer and easier. This can be done while adapting local rules to the national law that generalised the program, broadening the range of industries that can be distinguished, workshops and cultural associations are just two examples. The second relates to the need for greater time horizon to the benefits arising from the law which merely extends the transitional period during which there can be no eviction. For those who first received the distinction, that period is coming to an end. This requires enduring and more sustainable measures. Among them is the always controversial issue on rent controls. In the case of housing, it seems clear that the balance between landlord and tenant rights cannot be left solely to the laws of the market which has always led to situations of speculation, inequality and even 'death' of neighbourhoods, emptied of residents by owners who regard their property only as a financial asset (Atkinson 2018). In retail, the possibility of introducing anti-speculative control mechanisms is less discussed. However, even in the liberal city of New York there are references to the existence of commercial rent controls (Jahr,2008).

The third aspect concerns the possibility of not awarding recognition to units with scarce economic viability. The question of business viability is also controversial. Some actors involved in the decision-making of the program ' $\mathrm{LH}^{\prime}$ show discomfort with the distinction given to retail units perceived to be condemned in the short term, due to the characteristics of the business and the age of managers. To what extent and why is the artificial extension of inefficient and outdated businesses justified, as Findlay and Sparks (2014) warned, however in another context? The multiplication of cases where shops awarded cease their business will not denigrate the program? These issues require further study and comparative analysis with other cities and countries, which are still very scarce.

Everyone recognises the efforts of the Council team set up to assist the shopkeepers, the visual identity for the program given by the signpost, and the information available on 
the municipal website, but the interviewees think that it is necessary to go further by finding ways to enhance this heritage, integrating shops as storytelling elements with other initiatives aiming at the vitality of the districts. A possibility raised by some interviewees is to substitute the financial support to the shops, which they consider short, for other type of measures, discussed with and carry on by an entity, eventually a partnership between the municipality, the retailer's associations and representatives of the distinguished shops. With part of the available funding directed to professional management and communication, this entity could develop activities in several realms gaining from the foreign experiences of TCM or BIDs.

Taxes, financial, and technical support, besides advertising are important to consider, along with urban planning and governance. In areas where there is or is anticipated intense commercial use, planning should introduce restrictions on certain activities or changes that compromise the coming in or the continuity of retail premises, and on the suitability for shops of different dimensions, one crucial point of the Town Centre First policy in the UK. It has long been argued the need for integrated planning, as opposed to land use zoning with functional separation, to promote diversity and mixing activities, improve public spaces and the attractiveness of high streets and city centres. In addition to recognizing the complementarity of different retail formats (Clarke and Banga 2010), the literature, as well as policy recommendations (House of Commons, Housing, Communities and Local Government Committee 2019, 61) stress the need for 'a shift from the retail focused activities of high streets and town centres today to new uses and purposes which foster greater social interaction, community spirit and local identity and characteristics'. Multiactivity should be fostered through the provision of housing, work, pleasant meeting places, cultural events, and other initiatives able of offering experiences and dreams, and attracting people. The requalification of public space plays an important role as illustrated by the Lisbon riverfront and the downtown area even though this may lead to the privatization of some public space with the increase of the terraces that require consumption, as Cocola Gant (2015) and others have pointed out.

Most of the distinguished shops are in the Lisbon downtown, so the protection of these shops can be integrated into the discussion of the vitality and transformation of the city centre, within the framework of new forms of governance, calling for greater collaboration of the stakeholders in strategy decisions and in implementing the necessary measures. However, the relatively dispersed pattern of the shops distinguished tends to worsen with the increase in applications and will probably require a differentiation of public responses to integrate the shop stories richness with other vectors of urban management. A strategy with two levels can be envisaged. One, at municipal level, focused on the highest concentration in downtown and its larger catchment area. The other was seen as part of neighbourhood's offer, the revaluation of proximity and the new concerns with mobility and environmental issues, and then shared with local (sub municipal) authorities.

Retail will continue to be important in the city centre, but a decrease is predictable. At the same time the focus will be on more diverse offers in a multi-functional centre (Millington et al. 2015). Tourism, the economy of experience, the development of the evening economy, changes in mobility, the importance of events and the increased sensitivity to resilience and sustainability issues will play an increasing role in the planning and management of these areas (Coca-Stefaniak and Carroll 2014). Forms of shared governance in districts with a strong retail presence are virtually non-existent in Portugal (Guimarães 2018b), unlike 
other European countries, not only the United Kingdom, and even the US, which experimented with town centre management and BID models a long time ago. Several weaknesses and lack of professionalism in many businesses' associations contribute to this delay, a subject that should be addressed in order to move forward in the construction of living and sustainable downtown areas meaningful for different types of users.

\section{Acknowledgments}

We would like to thank the editors of the journal and the anonymous reviewers for their invaluable comments. We are also extremely grateful to Sofia Pereira, coordinator of the working group for 'Shops with a history' at the Lisbon City Council for the access to data of the program, to all who agreed to be interviewed, and to my colleagues Herculano Cachinho and Pedro Guimarães for their comments in the previous version of the text and for the photo provided by Cachinho.

\section{Disclosure statement}

No potential conflict of interest was reported by the author.

\section{Funding}

The research was supported by the FCT - Fundação para a Ciência e a Tecnologia, I.P. [Project PHOENIX-Retail-Led Urban Regeneration and the New Forms of Governance (PTDC/GES -URB/ 31878/2017)].

\section{Notes on contributor}

Teresa Barata-Salgueiro Professor Emeritus of the University of Lisbon, at IGOT (Institute of Geography and Spatial Planning) and senior researcher at the Centre for Geographical Studies (CEGL). As full professor, she taught at the University of Lisbon and other Portuguese and foreign universities mainly in Europe and Brazil and has integrated MSc and PhD dissertation juries in Portugal, France, Belgium and Spain.

Her research interests include city change and urban redevelopment; retail structure, modernization, and resilience; housing and social exclusion; urban policy.

She has been a member or leader of research projects funded by Portuguese and European institutions on these topics of research with the collaboration of Portuguese and foreign universities, and some applied projects for public authorities. She has published more than 150 titles on her main research subjects.

\section{ORCID}

Teresa Barata-Salgueiro (iD) http://orcid.org/0000-0002-1509-5087

\section{References}

Arino Barrera, A. 2009. "El Passeig de Gracia entre los Servicios Y el Comercio." In Cidade e Comércio. A Rua Comercial na Perspectiva Internacional, ed. C. Carreras and S. M. Pacheco, 199-209. Rio de Janeiro: Armazém das Letras.

Atkinson, A. 2018. "Necrotecture: Lifeless Dwellings and London's Super-rich." International Journal of Urban and Regional Research. doi:10.1111/1468-2427.12707. 
Bäckström, K. 2006. "Understanding Recreational Shopping: A New Approach." International Review of Retail, Distribution and Consumer Research 16 (2): 143-158. doi:10.1080/ 09593960600572167.

Balsas, C. 1999. Urbanismo Comercial em Portugal ea Revitalização do Centro das Cidades. Lisbon: GEPE, Observatório do Comércio.

Balsas, C. 2001. "Commerce and the European City Center: Modernization, Regeneration and Management." European Planning Studies 9 (5): 677-682. doi:10.1080/713666504.

Barata-Salgueiro, T. 2013. "Do Centro às Centralidades Múltiplas." In A Nova Vida do Velho Centro nas Cidades Portuguesas eBrasileiras, ed. J. A. R. Fernandes and M. E. B. Sposito, 13-29. Porto: Faculdade de Letras da Universidade do Porto, Centro de Estudos de Geografia e Ordenamento do Território.

Barata-Salgueiro, T., L. Mendes, and P. Guimarães. 2017. “Tourism and Urban Changes: Lessons from Lisbon." In Tourism and Gentrification in Contemporary Metropolises. International Perspectives, ed. M. Gravari-Barbas and S. Guinand, 255-275. London: Routledge.

Cachinho, H. 1992. "L'Urbanisme Comercial: Un Instrument au Service de L'amenagement des Activités Commerciales." In Retailing, Public Policy and Urban Retail Planning, ed. T. BarataSalgueiro, 247-260. Lisbon: GECIC.

Cachinho, H. 2002. O Comércio Retalhista Português: Pós-modernidade, Consumidores eEspaço. Lisbon: GEPE, Observatório do Comércio.

Cachinho, H. 2006. "Consumactor: da Condição do Indivíduo na Cidade Pós-moderna." Finisterra. Revista Portuguesa de Geografia 41 (81): 33-56. doi:10.18055/Finis1461.

Cachinho, H. 2011. "Urban Retail Dinamics: From Shopping Spaces to Consumer Places." In Retail Planning for the Resilient City: Consumption and Urban Regeneration, ed. T. Barata-Salgueiro and H. Cachinho, 147-168. Lisbon: Centro de Estudos Geográficos da Universidade de Lisboa.

Cachinho, H. 2015. "Avenida da Liberdade: From the Bourgeoisie Promenade to the Showcase of International Capital." In City, Retail and Consumption, ed. L. D'Alessandro, 35-47. Naples: Università degli studi di Napoli 'L'Orientale'.

Cachinho, H., and T. Barata-Salgueiro. 2016. "Os Sistemas Comerciais Urbanos em Tempos de Turbulência: Vulnerabilidade eNíveis de Resiliência." Finisterra. Revista Portuguesa de Geografia 51 (101): 89-109. doi:10.18055/Finis4134.

Carreras, C., and L. Frago. 2016. "Patrimonio Comercial Y Turismo. Los Establecimientos Emblemáticos de Barcelona Turística." CENÁRIO 4 (6): 9-26. doi:10.26512/revistacenario. v4i6.18297.

Chamusca, P., J. A. R. Fernandes, M. R. Lopes, and F. Tavares. 2017. “O Comércio como Património: O Projeto 'Lojas com História'." In As Dimensões ea Responsabilidade Social da Geografia. Atas do XI Congresso da Geografia Portuguesa, ed. T. S. Marques, 65-67. Porto: Faculdade de Letras da Universidade do Porto (e-book).

Chaney, D., M. Pulh, and R. Mencarelli. 2018. "When the Arts Inspire Businesses: Museums as a Heritage Redefinition Tool of Brands." Journal of Business Research 85: 452-458. doi:10.1016/j. jbusres.2017.10.023.

Clarke, I., and S. Banga. 2010. "The Economic and Social Role of Small Stores: A Review of UK Evidence." The International Review of Retail, Distribution and Consumer Research 20 (2): 187-215. doi:10.1080/09593961003701783.

CML (Câmara Municipal de Lisboa). 2015. “Aprova oPrograma «Lojas com História» ea Constituição do Respetivo Grupo de Trabalho Deliberação N.o 99/CM/2015." Boletim Municipal No1097 240: 20-21.

Coca-Stefaniak, J. A., and S. Carroll. 2014. "Managing Town Centres during the Crisis: From Retailfocussed Management to the Experience Economy and Beyond." In Evolving High Streets: Resilience \& Reinvention, Perspectives from Social Science, ed. N. Wrigley and E. Brookes, 29-31. Southampton: University of Southampton.

Coca-Stefaniak, J. A., C. Parker, and P. Rees. 2010. "Localisation as a Marketing Strategy for Small Retailers." International Journal of Retail \& Distribution Management 38 (9): 677-697. doi:10.1108/ 09590551011062439. 
Cocola Gant, A. 2015. "Tourism and Commercial Gentrification". In The ideal city. Between myth and reality. RC21 International Conference. Urbino, 27th-29th August, 2015.

D’Alessandro, L. 2015. "Per Una Nuova Agenda di Ricerca su Consumo eCittá." In City, Retail and Consumption, ed. L. D. Alessandro, 339-347. Naples: Università degli studi di Napoli 'L'Orientale'.

D'Alessandro, L., and A. Salaris. 2011. "Retail as an Instrument for the Revitalization of City Center: Considerations from Two Italian Medium-sized Cities." In Retail Planning for the Resilient City. Consumption and Urban Regeneration, ed. T. Barata-Salgueiro and H. Cachinho, 299-315. Lisbon: Centro de Estudos Geográficos.

Davies, R., ed. 1995. Retail Planning Policies in Western Europe. London: Routledge.

De Simone, L. 2017. "Espacios de Consumo Y Urbanismo de Retail: Construyendo la Ciudad del Consumo en Santiago de Chile." In Ciudad, Comercio Urbano Y Consumo. Experiencias desde LatinoAmerica Y Europa, ed. J. Gasca and P. Olivera, 99-116. Ciudad de México: Universidad Nacional Autónoma de Méxi.

Fernandes, J. A. R. 1994. "Urbanismo Comercial. A Experiência Portuguesa." Revista da Faculdade De Letras da Universidade do Porto 10/11: 105-125.

Fernandes, J. A. R. 2007. "As Actividades Comerciais ea Valorização das Áreas Centrais." Inforgeo 2021: 129-135.

Findlay, A., and L. Sparks. 2014. "High Streets and Town Centres Policy." In Evolving High Streets; Resilience \& Reinvention, ed. N. Wrigley and E. Brookes, 12-15. Southampton: University of Southampton, ESRC (Economic \& Social Research Council).

Goss, J. 1993. "The Magic of the Mall: An Analysis of Form, Function, and Meaning in the Contemporary Retail-built Environment." Annals of Association of American Geographers 83 (1): 392-403. doi:10.1111/j.1467-8306.1993.tb01921.x.

Guimarães, P. 2015. O Planeamento Comercial Em Portugal. Os Projectos Especiais de Urbanismo Comercial. PhD thesis in Geography and Planning. Lisbon: Universidade de Lisboa.

Guimarães, P. 2018b. "Town Centre Management: Outlook from Portugal"." Planning Practice \& Research 33 (1): 18-33. doi:10.1080/02697459.2017.1378967.

Guimarães, P. 2018a. "The Transformation of Retail Markets in Lisbon: An Analysis through the Lens of Retail Gentrification." European Planning Studies 26 (7): 1450-1470. doi:10.1080/ 09654313.2018.1474177.

Guy, C. 2007. "Is 'Demonstration of Need' Necessary in Retail Planning Policy?" Regional Studies 41 (1): 131-137. doi:10.1080/00343400600990467.

Harvey, D. 1989. "From Managerialism to Entrepreneurialism. The Transformation in Urban Governance in Late Capitalism." Geografiska Annaler 71: 3-17. doi:10.2307/490503.

House of Commons, Housing, Communities and Local Government Committee. 2019. High Streets and Town Centres in 2030. London: Parliamentary Copyright House of Commons.

Jacobs, J. 1961. The Death and Life of Great American Cities. NYork: Vintage Book.

Jahr,N. July, 21st, 2008. "May Be Beloved Shops Don't Have to Disappear." (acessed 30 Oct 2018). https://citylimits.org/2008/07/21/maybe-beloved-shops-dont-have-to-disappear/

Klingman, A. 2007. Brandscapes: Architecture in the Experience Economy. Cambridge, Mass: MIT Press.

Tselios, V., D. Lambiri, and L. Dolega. 2018. "Performance within a Recession: The Converging Trajectories of Retail Centres in the UK." Regional Science Policy and Practice 1(4): 347-365. doi:10.1111/rsp3.12144.

Lipovetsky, G. 2006. Le Bonheur Paradoxal. Translated by P.Xavier. Lisboa: Edições 70.

Mérenne-Schoumaker, B., and A. Browet. 1988. 1993. Localisation Du Magasin. Guide Pratique. Brussels: Comité Belge de la Distribution.

Millington, S., N. Ntounis, C. Parker, and S. Quin. 2015. Multifunctional Centres: A Sustainable Role for Town and City Centres. Manchester: Institute of Place Management.

Molotch, H. 1976. "The City as a Growth Machine: Toward a Political Economy of Place." American Journal of Sociology 82 (2): 309-332. https://www.jstor.org/stable/2777096.

Najmi, I., W. D. Pratiwi, and I. B. Harun. 2015. "Public Agencies Engagement on Heritage Building in Bandung Shopping Street: Intervening the Visible." Procedia - Social and Behavioral Sciences 184: 372-379. doi:10.1016/j.sbspro.2015.05.105. 
Olivera, P. 2015. "New Consumption of Urban Spaces in Mexico City." In City, Retail and Consumption, ed. L. D'Alessandro, 385-393. Naples: Università degli studi di Napoli 'L'Orientale'.

Parker, C., N. Ntounis, S. Quin, and S. Millington. 2016. Identifying Factors that Influence Vitality and Viability. Manchester: Institute of Place Management.

Peck, J., N. Theodore, and N. Brenner. 2013. "Neoliberal Urbanism Redux?" International Journal of Urban and Regional Research 37 (3): 1091-1099. doi:10.1111/1468-2427.12066.

Pine, B. J., and J. H. Gilmore. 1999. The Experience Economy. Work Is Theatre and Every Business a Stage. Boston: Harvard Business School Press.

Rabbiosi, C. 2016. "Place Branding Performances in Tourist Local Food Shops." Annals of Tourism Research 60: 154-168. doi:10.1016/j.annals.2016.07.002.

Roozen, I. 2019. “The Influence of External Design Elements on Clothing Store Entry Intentions for Recreationally and Task-oriented Female Clothing Shoppers." The International Review of Retail, Distribution and Consumer Research 29 (4): 409-429. doi:10.1080/09593969.2019.1581075.

Silveira, M. L. 2016. "Introducción \& Buenos Aires Enclave de Modernidade y Pobreza." In Circuitos de la Economía Urbana. Ensayos sobre Buenos Aires ySão Paulo, ed. M. L. Silveira, 13-67. Buenos Aires: Editorial Café de las Ciudades.

Thomsen, L. 2018. "Retailing in Places of World Heritage, Transition and 'Planned Authenticity'." Geoforum 91: 245-252. doi:10.1016/j.geoforum.2018.03.016.

Veblen, T. 1899. 1970. The Théory of the Leisure Class. Translated by L. Évrard. Paris: Gallimard.

Wrigley, N., and L. Dolega. 2011. "Resilience, Fragility, and Adaptation: New Evidence on the Performance of UK High Streets during Global Economic Crisis and Its Policy Implications." Environment \& Planning A 43: 2337-2363. doi:10.1068/a44270.

Yunus, R. M., Z. Samadi, and D. Omar. 2015. "Making of 'Great Heritage Street." Procedia - Social and Behavioral Sciences 168: 365-372. doi:10.1016/j.sbspro.2014.10.242.

Zukin, S. 2009. "Changing Landscapes of Power: Opulence and the Urge for Authenticity." International Journal of Urban and Regional Research 33 (2): 543-553. doi:10.1111/j.14682427.2009.00867.x.

Zukin, S. 2012. "The Social Production of Urban Cultural Heritage: Identity and Ecosystem on an Amsterdam Shopping Street." City, Culture and Society 3: 281-291. doi:10.1016/j.ccs.2012.10.002. 